\title{
A notation to measure and improve efficiency with regards to Integration, Validation and Verification of systems

\author{
Integration Verification Validation Assessment Notation (IV $\left.{ }^{2} \mathrm{AN}\right)$
}

\author{
David Gouyon*, Stéphane Chaigneau**, \\ Jean-Marc Quiot***, Nicolas Veaux****, Vincent Chapurlat ***** \\ * Centre de Recherche en Automatique de Nancy, UMR 7039 CNRS Nancy-Université \\ Faculté des Sciences et Techniques, BP 239, Vandoeuvre-lès-Nancy Cedex, FRANCE,david.gouyon@,cran.uhp-nancy.fr \\ **DGA-ETBS, Rocade Est-Echangeur de Guerry,18021 BOURGES, FRANCE, stephane.chaigneau@dga.defense.gouv.fr \\ ***Renault, 1 avenue du Golf, 78288 Guyancourt,FRANCE, jean-marc.quiot@renault.com \\ **** Intertechnique-Zodiac, 61 rue Pierre Curie, 78370 PLAISIR, FRANCE, nveaux@intertechnique.zodiac.com \\ ***** Laboratoire de Génie Informatique et d'Ingénierie de Production, \\ Parc Scientifique G. Besse, Site EERIE de l'EMA, 30035 Nimes Cedex, FRANCE, vincent.chapurlat@ema.fr
}

\begin{abstract}
Integration, Verification \& Validation processes are key activities regarding the Quality, Cost and Delivery time, and thus has a huge impact on the projects profitability. IVV processes are complex and have to take into account in a coherent way various elements such as skills, organizations, means, process and risk management. Therefore, a maturity model is well adapted to describe how to evaluate and improve an industrial context. In order to help managers to assess their IVV process and reach a performance level corresponding to their goal, an assessment notation has been carried out (IV $\left.{ }^{2} \mathrm{AN}\right)$. As the main idea is to improve step by step and not to jump directly to the higher level, the assessment notation proposes some ideas for a smooth deployment to improve and gain in development performance. This paper describes this approach, based on criteria which seem important to the INCOSE's French Chapter (AFIS) IVVQ Working Group and shared by several industrial companies.
\end{abstract}

Keywords: Maturity model, IVV assessment and improvement, Integration, Validation, Verification.

\section{INTRODUCTION}

As a part of system development effort, the Integration, Verification \& Validation (IVV) effort is a key activity regarding the Quality, Cost and Delivery time (QCD) objectives, and thus has a major impact on the projects profitability. These metrics based on QCD have a direct link with the customer satisfaction and the capacity of the enterprise to maintain or increase his market parts. The management of these metrics through the IVV effort is essential for enterprises.

As a key activity, IVV is complex and axes such as skills, organizations, means, process, risk management have to be taken into account in coherence all together. In order to asses Systems Engineering practices and processes, as it is done for Interoperability of task forces with the Organisational Interoperability Maturity Model (Clark \& Jones 1999) or the
LISI maturity model (Kanusis \& Anderson 2004), maturity models have been used for years (e.g. CMMI ${ }^{1}$ (Riefer 2000, Chrissis et al. 2003, Basque 2006), or $\mathrm{SPICE}^{2}$ (ISO/IEC 15504)), but mainly for development (SEI 2006) and acquisition (SEI 2008) processes. As far as Integration, Verification and Validation (IVV) processes are concerned, such models may not provide any satisfactory answer (Staples et al. 2007, Staples and Niazi 2008) for the IVV decision maker against some of the following issues:

- maturity models are generally process centric, thus excluding aspects related to organization, IVV enabling products (e.g. tools, environment...) and technology risk assessment;

\footnotetext{
${ }^{1}$ Capability Maturity Model Integration is a process improvement approach that provides organizations with the essential elements of effective processes.

2 Software Process Improvement and Capability dEtermination is a framework for process assessment jointly developed by ISO and IEC.
} 
- IVV processes may be only addressed at the highest levels of some maturity models: e.g. CMMI process areas Product Integration, Verification and Validation only appear at maturity level 3;

- the scope of maturity models may be larger than IVV discipline, leading to measure a whole set of processes in the organization in order to gather all relevant information for IVV improvement decision making.

These issues lead the IVVQ Working Group of the AFIS ${ }^{3}$, which is composed of industrial and academic members working on the development and the formalization of IVV good practices, to propose $\mathrm{IV}^{2} \mathrm{AN}$ (Integration Verification Validation Assessment Notation), a complementary and pragmatic approach to existing maturity models supporting decision. This "new approach for IVV assessment" is first a good tool for understanding an organization context and then a set of ideas for improving IVV activities. It is the main object of this paper.

After having highlighted the importance of an efficient tailoring of IVV activities in the next paragraph, this paper proposes a new approach for maturity assessment and then an IVV maturity scale.

\section{ABOUT THE IMPORTANCE OF AN EFFICIENT TAILORING OF IVV ACTIVITIES}

\subsection{IVV as key processes}

The purpose of the integration process is to build the systemof-interest by progressively combining system elements in accordance with the architectural design requirements and the integration strategy. This process is successively repeated in combination with the verification and validation processes (Haskins 2006).

The purpose of the verification process is to confirm that all requirements are fulfilled by the system elements, i.e. that the system has been done right, while the purpose of the validation process is to confirm that the realized system complies with stakeholders' requirements and is subject to approval by the project authority and key stakeholders (Haskins 2006).

As these definitions show it, IVV processes are key technical processes of systems engineering because they ensure that the system of interest is designed and delivered according to stakeholders' requirements.

3 Association Française d'Ingénierie Système, http://www.afis.fr/, the French chapter of the INCOSE - International Council on Systems Engineering, http://www.incose.org/

\subsection{Tailoring IVV activity}

Even if the IVV are key processes to ensure the respect of requirements of a developed system, the QCD compromise relies on the balance of IVV efforts of the organization. These efforts imply at least the following axes:

- Organization: the responsibilities and the links between the different entities of the enterprise (or suppliers) which are involved in the IVV activity should be well defined. This organization has to be defined in accordance with the other axis of this chapter;

- Process and methods: specific processes and methods have to be deployed in order to ensure good practices of IVV activities (identification of the activity, strategy, quality level, traceability, constant improvement ...). It is essential to adapt them with the level of complexity of the system;

- Skills: it is necessary to identify and recognize that IVV needs specific competencies in order to manage and improve them. This axe is particularly important: a lack of skill should have a big impact on the others axis of the IVV activities (e.g. a very high level of skill could allow less effort on the process and method activities);

- IVV hardware and software means: as many other processes, IVV have to be supported by tools. It implies that means have to be budgeted, maintained and optimized;

- Risks management: it is not sufficient to have good process, good skills, good organization and good means if people who takes decisions, does not consider this activities with a minimum of methodology, including criteria considering the maturity of technologies. The main risk is to have a bad management of the IVV effort, then a bad QCD of the system and then a bad impact on the enterprise profits.

The risk assessment should guide the tailoring of the IVV effort for each axe defined previously. In other words, the organization shall tailor its IVV Process to make the system comply with its Quality/Cost/Delivery objectives, regarding requirements.

\subsection{Towards a efficient tailoring}

Various IVV effort strategies are possible for reaching products' QCD targets. Fig. 1 illustrates that the effort has to be tailored in order to avoid over cost and delay overrun:

- The curve at the top shows a tight-schedule strategy; it may however induce over quality and excessive IVV efforts.

- The curve at the bottom represents a tight-budget strategy; related risks in this case are insufficient IVV efforts and under quality.

- The continuous curve in the middle illustrates an optimized strategy so as to comply with the QCD objectives of a product design and production phases. 


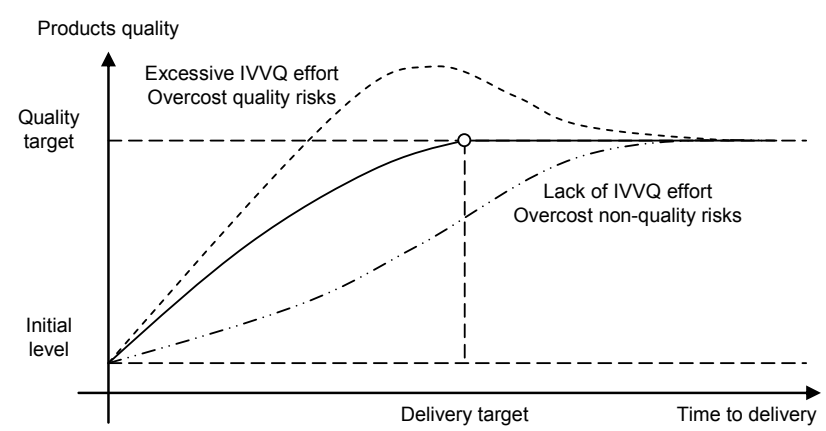

Fig. 1. Strategies to achieve product QCD objectives

It is important to underline that this tailoring activity should not be under estimated. Thus one of the sub activity should be to assess its IVV maturity level to highlight and decide which process areas features (i.e.: processes, methods, tools, skills ...) have to be improved. These are the reasons why we need a structured approach to reach the "continuous curve".

\section{A NEW APPROACH FOR IVV ASSESSMENT}

As identified in the previous paragraph, it is essential for companies to tailor their IVV activities in function of their QCD objectives. In order to evaluate the maturity level of such activities, this paragraph introduces the approach proposed by the working group on IVV of AFIS, and in particular the link with the risks management.

The goal of this approach is to help the definition of an IVV process maturity level, in order to:

- Assess the company IVV maturity based on factual data,

- Evaluate a maturity objective to be reached,

- Offer an improvement approach tailored to this objective against the features identified in paragraph 2 :

- Company's organization: which responsibilities for which entities? From an organization which does not take in account IVV to a specific organization to optimize them;

- Processes and methods: definition and implementation. From a stage in which neither processes nor methods are used for IVV activities to a constant process improvement using measurement and improvement;

- Competencies: qualification, skills, knowledge. From a stage in which no specific competencies are identified to an efficient competences management;

- Means and Tools: ability for the hardware/software resources to support IVV processes. From a stage in which no means are identified or planned to the use of appropriate and relevant means;

- Technologies: ability to tailor the process to the product technology contents. From no use of technology to notions such as "Technology
Readiness Level (TRL4)" or "Integration Readiness Level (IRL5)" (Mankins 1995);

- Prepare an argumentation to convince the management (launching an improvement project needs a lever, a triggering and supporting event),

- Drive the IVV improvement efforts towards a Quality/Cost/Delivery balance,

- Manage the risk. Each decision to improve or not the IVV level of maturity has an impact on the risks: technical risk (e.g. impact on the quality), project risk (e.g. impact on the delay and cost) and use risk (e.g. impact on the security of the system). A risk analysis should be done to help the decision maker to drive efficiently the improvement of the IVV maturity.

By applying this approach, in other words by defining and applying a strategy to upgrade elements of organization, methods, competencies, means, technologies and risk management, the company will improve its IVV maturity, as shows Fig. 2.

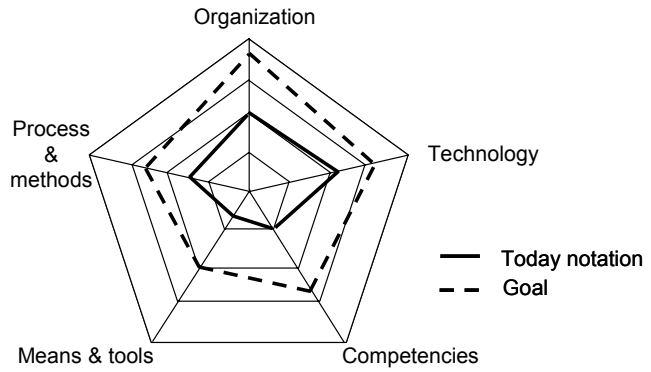

Fig. 2. Example of strategy for IVV maturity improvement

Peer reviews are a good example for simple and basic action with huge and important maturity improvement. Each person can after several reviews understand the importance of this action and then propose to start by document standardization, process formalism, etc...

IVV activities aim to mitigate technology risks through the provision of objective evidences. Consequently, the necessary effort and maturity for the IVV of a system is strongly depending on the maturity of technologies to be

4 TRL: Technology Readiness Level is a measure used by some United States government agencies and many major world's companies (and agencies) to assess the maturity of evolving technologies (materials, components, devices, etc.) prior to incorporating that technology into a system or subsystem. Generally speaking, when a new technology is first invented or conceptualized, it is not suitable for immediate application. Instead, new technologies are usually subjected to experimentation, refinement, and increasingly realistic testing. Once the technology is sufficiently proven, it can be incorporated into a system/subsystem.

5 IRL: Integration Readiness Level is a systematic measurement of the interfacing of compatible interactions for various technologies and the consistent comparison of the maturity between integration points. 
integrated, verified or validated, as shown by many industrial examples. A technology risk driven approach enables the decision maker to assess the level of technology risk of a project so as to tailor the IVV organization, processes and methods, tools, skills and the related effort.

Several approaches exist in a lot of industries (Innovation Check list (ICL), Design2Quality (D2Q)...) but the Technology Readiness Level / Integration Readiness Level
(TRL / IRL (Mankins 1995)) approach is a well known example of technology risk driven approach that enables to compare the current maturity of a given technology with the level of maturity needed for its successful integration in a system. The TRL/IRL assessment is based on a scale illustrated on an example by Fig. 3. In this scale, level 1 corresponds to the lowest level of maturity and levels 9 (TRL) and 5 (IRL) correspond to the highest levels of maturity.

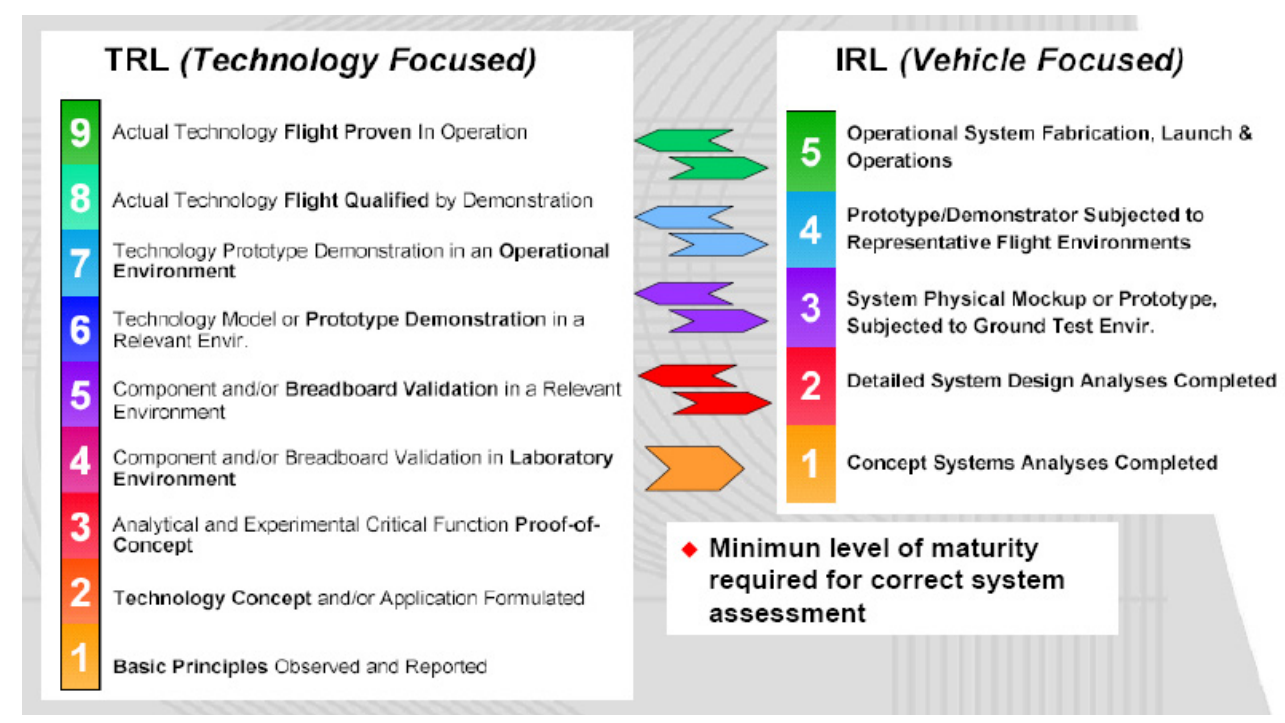

Fig. 3. Example of TRL / IRL scale

The decision maker will have to identify the risk, appreciate and classify it and then launch an appropriate action plan to validate this new technology for the considered project.

\section{AN IVV MATURITY SCALE: IV²AN}

Each organization has to know its current status and its goal for the next several years. The most important issue is to be coherent (including partners like Tier 1, 2 or 3) in order to develop and produce a product well adapted to the initial need (market). Fig. 2 shows an example of an organization situation (strength and weaknesses) and what should be the same company few years later.

To help the manager to evaluate and improve its IVV maturity level, the $\mathrm{IV}^{2} \mathrm{AN}$ approach proposes an IVV maturity scale. Because the AFIS working group IVVQ thinks the current CMMI is not completely adapted and because CMMI level 5 seems not to be "THE Graal" for all systems in all contexts (Staples et al. 2007), a more progressive model is often needed.

The proposed progressive 8-level scale defines assessment criteria which are more related to IVV processes than generic maturity models such as CMMI. This scale has to be understood as a guide for managers. First, identify the estimated level your organization is, (normally you should be non-homogeneous) and then select the action just upper you are.

The 8-level scale is described in Table 1, which presents on one side the maturity level (from 0 to $G$ ), and on the other side the organization, process / method, competences / skills, hardware / software means and risks management views. The cells of Table 1 show the criteria corresponding to the maturity level for the defined areas. In parallel with the IVV maturity level, the corresponding CMMI level is given. 


\begin{tabular}{|c|c|c|c|c|c|c|c|}
\hline Level & Company Organization & Process - Methods & Competences & $\begin{array}{c}\text { Hardware / Software V\&V } \\
\text { Means }\end{array}$ & $\begin{array}{c}\text { Risks } \\
\text { management } \\
(\text { TRL / IRL) }\end{array}$ & & \\
\hline $\mathbf{0}$ & & $\begin{array}{l}\text { Neither processes nor methods for } \\
\text { V\&V activities. } \\
\text { The designer choose the method by } \\
\text { himself } \\
\text { No measure of the activity (Cost...) }\end{array}$ & $\begin{array}{c}\text { Neither competences are } \\
\text { identified, nor is a training } \\
\text { plan associated }\end{array}$ & $\begin{array}{l}\text { Neither means are identified, nor } \\
\text { planned }\end{array}$ & $\begin{array}{l}\text { Technologies IRL } \\
\text { / TRL are not } \\
\text { taken in account in } \\
\text { products V\&V }\end{array}$ & \multirow[b]{5}{*}{ 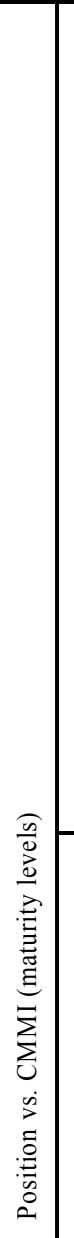 } & \multirow{5}{*}{ 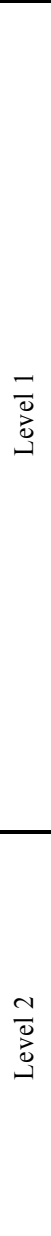 } \\
\hline $\mathbf{A}$ & $\begin{array}{l}\text { The V\&V is not seen as a } \\
\text { specific activity in the } \\
\text { company organization. }\end{array}$ & $\begin{array}{l}\text { Neither processes nor methods for } \\
\text { V\&V activities. } \\
\text { No measure of the activity (Cost...) }\end{array}$ & Idem 0 & $\begin{array}{l}\text { The means are not budgeted, } \\
\text { managed, nor maintained }\end{array}$ & Idem 0 & & \\
\hline B & $\begin{array}{c}\text { A specific responsibility is } \\
\text { identified }\end{array}$ & $\begin{array}{c}\text { Beginnings of methods } \\
\text { Identification of activity through } \\
\text { project management } \\
\text { No measure of the activity (Cost...) }\end{array}$ & $\begin{array}{l}\text { Competence based on } \\
\text { technical experience } \\
\text { (empiric knowledge) } \\
\text { Partial training based on } \\
\text { individual will }\end{array}$ & $\begin{array}{l}\text { Means are known and used. The } \\
\text { means are not budgeted, } \\
\text { managed, nor maintained }\end{array}$ & Idem 0 & & \\
\hline $\mathrm{C}$ & $\begin{array}{c}\text { A specific responsibility is } \\
\text { identified }\end{array}$ & $\begin{array}{c}\text { Local but non-homogeneous } \\
\text { processes are defined (ex. : structures, } \\
\text { EMI, integration,...) } \\
\text { Suppliers V\&V strategy is not taken } \\
\text { in account } \\
\text { Activities are planned and budgeted } \\
\text { by project management }\end{array}$ & $\begin{array}{l}\nabla \& \nabla \text { is a recognized } \\
\text { competence based on } \\
\text { technical knowledge (eg on } \\
\text { the "system-of-interest") } \\
\text { specialized and local } \\
\text { (regulations/standards, } \\
\text { processes, tools, methods) } \\
\text { Local training based on } \\
\text { individual will }\end{array}$ & $\begin{array}{l}\text { Some means are managed and } \\
\text { maintained. Needs are neither } \\
\text { budgeted not planned } \\
\text { Compliance of the means to the } \\
\text { needs is not justificated } \\
\text { Needs and corresponding means } \\
\text { are not updated through project } \\
\text { life }\end{array}$ & Idem 0 & & \\
\hline D & $\begin{array}{c}\text { V\&V competences are } \\
\text { gathered in organization's } \\
\text { entities } \\
\text { Activities and means are } \\
\text { planned and budgeted in } \\
\text { relation with the company } \\
\text { investments } \\
\text { Impartiality of validation } \\
\text { vs. conception for } \\
\text { arbitration capacity }\end{array}$ & $\begin{array}{l}\text { A V\&V defined process appears. A } \\
\text { V\&V strategy is defined } \\
\text { The quality level goal is defined } \\
\text { The activity is measured (coverage } \\
\text { level...) according to the objectives }\end{array}$ & $\begin{array}{c}\text { The competencies converge } \\
\text { : between system levels and } \\
\text { organization entities } \\
\text { Competences are managed } \\
\text { and harmonized but } \\
\text { training is not planned } \\
\text { V\&V management } \\
\text { competencies appears (e.g. } \\
\text { on the "enabling product") }\end{array}$ & $\begin{array}{l}\text { The means are budgeted, } \\
\text { managed and maintained (but no } \\
\text { configuration management) } \\
\text { The means pass through an } \\
\text { acceptation, but not } \\
\text { systematically documented } \\
\text { Needs and corresponding means } \\
\text { are updated through project life }\end{array}$ & Idem 0 & & \\
\hline $\mathbf{E}$ & $\begin{array}{l}\text { V\&V competences are } \\
\text { gathered in organization's } \\
\text { entities }\end{array}$ & $\begin{array}{l}\text { A mapping of the organization's } \\
\text { processes allow to minimize } \\
\text { interfaces } \\
\text { Capitalization of measures and risk } \\
\text { management activity } \\
\text { A traceability is ensured through all } \\
\text { the V\&V process data }\end{array}$ & $\begin{array}{l}\text { Competences are managed } \\
\text { and harmonized. The } \\
\text { training is planned }\end{array}$ & $\begin{array}{l}\text { The means are budgeted } \\
\text { The means pass through a } \\
\text { documented acceptation } \\
\text { The means are configuration } \\
\text { managed } \\
\text { The means are communalized } \\
\text { between projects } \\
\text { The organization acquires } \\
\text { complex means }\end{array}$ & $\begin{array}{l}\text { Capacity to use the } \\
\text { TRL/IRL notion }\end{array}$ & & $\frac{m}{0}$ \\
\hline $\mathbf{F}$ & Idem E & $\begin{array}{l}\text { V\&V risk management taken into } \\
\text { account } \\
\text { The process is tailored to mmet } \\
\text { requirement and technological risks, } \\
\text { technical, delay and cost constraints } \\
\text { on all the projects } \\
\text { The V\&V strategy helps to optimize } \\
\text { globally the development processes } \\
\text { and mitigate risks as soon as possible } \\
\text { (project stop is possible) }\end{array}$ & $\begin{array}{l}\text { Competences levels are } \\
\text { tailored to meet the needs }\end{array}$ & $\begin{array}{l}\text { The means are optimized vs. } \\
\text { Organization goals (efficiency) : } \\
\text { Cost, availability, complexity,... } \\
\text { (e.g. : formal tools, specific rigs, } \\
\text { agile methods,...) }\end{array}$ & $\begin{array}{l}\text { Use of TRL/IRL in } \\
\text { the V\&V strategy }\end{array}$ & & $\frac{\dot{\sigma}}{\stackrel{0}{0}}$ \\
\hline G & $\begin{array}{l}\text { A specific organization to } \\
\text { optimize the } V \& V \text { goals } \\
\text { and upgrade it constantly }\end{array}$ & $\begin{array}{l}\text { Constant process improvement using } \\
\text { measurement and anticipation }\end{array}$ & $\begin{array}{l}\text { Forecast competences } \\
\text { management is efficient }\end{array}$ & $\begin{array}{l}\text { Use of TRL/IRL in the V\&V } \\
\text { means strategy }\end{array}$ & Risk anticipation & & 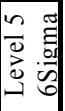 \\
\hline
\end{tabular}

Table 1. IV²AN Maturity scale 


\section{CONCLUSION AND PERSPECTIVES}

$\mathrm{IV}^{2} \mathrm{AN}$ is not a revolution but simply a basic tool for management. TRL/IRL is not unique in the industry but is a pragmatic way to identify risks and select the adapted IVV plan. The $I^{2} A N$ approach does not propose one typical organization based or turnkey solutions because it does not exist. It belongs to each company to analyze and find its current IVV maturity level and, in function of its objectives, organization, methods, skills, means and risk management, to adapt its IVV strategy in function of its problems (Fig. 4).

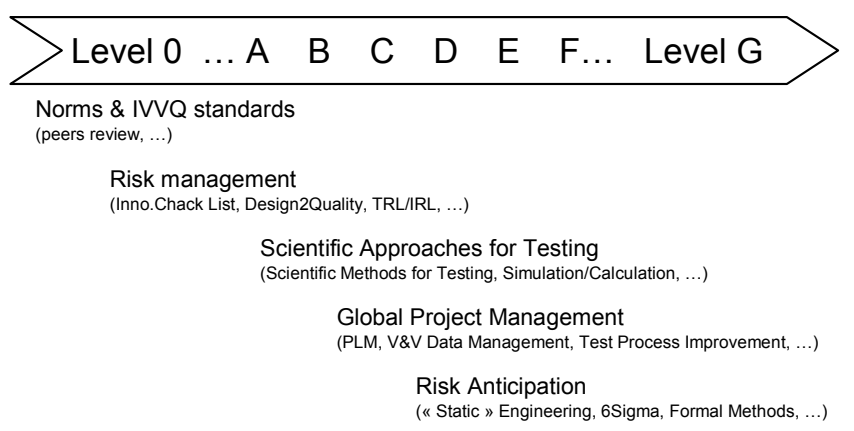

Fig. 4. Example of actions to improve IVV situation

The key word is "maturity" and "maturity" cannot be bought. It is impossible to use "Metrics" before "standards", and it is also impossible to practice "Risks Anticipation" before "Risk Management", and so on.

Organizations have to select their improvement actions so as to perform progressive and achievable gaps, just upper than they are, to improve the situation, and to avoid too important "breaks", which often bring difficult situations.

Perspectives of the work presented in this paper imply the refinement of the matrix criteria in order to improve the definition of each level, and case studies in order to ensure the validity of the $\mathrm{IV}^{2} \mathrm{AN}$ notation. The scale could also be specialized to some specific domains. Tutorials will be proposed in order to help companies to upgrade the maturity level of their IVV.

\section{REFERENCES}

Basque R. (2006). CMMI - un itinéraire fléché vers le Capability Maturity Model Integration Version $1.2\left(2^{\text {nd }}\right.$ edition), Dunod, ISBN 2-10-049711-1.

Chrissis, M., Konrad, M., Shrum, S. (2003). CMMI: Guidelines for Process Integration and Product Improvement. Addison-Wesley Professional, ISBN 0321-15496-7.

Clark, T., Jones, R. (1999), Organisational Interoperability Maturity Model for C2. Proceedings of the 1999 Command et Control Research and Technology Symposium, US Naval War College, Rhode Island.
Haskins C. (ed.) (2006), Systems Engineering Handbook, a guide for system life cycle processes and activities, International Council on Systems Engineering, INCOSE TP-2003-002-03.

International Organization for Standardization - International Electrotechnical Commission (2004). ISO/IEC 15504: Information technology - Process Assessment.

Kanusic M., Anderson W. (2004). Measuring systems interoperability: challenges and opportunities, Software Engineering Measurement and Analysis, Technical Note, Carnegie Mellon University.

Mankins, J. (1995). Technology Readiness Levels, White Paper of the Advanced Concepts Office, Office of Space Access and Technology, NASA.

Reifer, D. (2000) The CMMI: it's formidable. The Journal of Systems \& Software, vol. 50, pp. 98-99.

Software Engineering Institute (2006), CMMI for Development, Version 1.2, Carnegie Mellon University, August.

Software Engineering Institute (2008), CMMI for Acquisition, Version 1.2, Carnegie Mellon University, August.

Staples, M., Niazi, M., Jeffery, R., Abrahams, A., Byatt, P., Murphy, R. (2007). An exploratory study of why organizations do not adopt CMMI. The Journal of Systems \& Software, vol. 80, pp. 883-895.

Staples, M., Niazi, M. (2008). Systematic review of organizational motivations for adopting CMM-based SPI. Information and Software Technology, vol. 50, pp. 605-620. 